2. Таранов Н. Н. Художественно-образная выразительность шрифтов: монография. Волгоград: Перемена. 2000. 168 с.

DOI https://doi.org/10.30525/978-9934-26-117-6-39

\title{
АНІМАЛІСТИЧНІ ОБРАЗИ В ТВОРЧОСТІ ВІРИ БАРИНОВОЇ-КУЛЕБИ
}

\author{
Петрук P. I. \\ заслужений діяч мистеитв України, \\ дочент кафедри монументально-декоративного \\ і сакрального мистеитвва
}

Київська державна академія декоративно-прикладного мистецтва і дизайну імені Михайла Бойчука м. Київ, Україна

Творчий доробок відомої української художниці Віри Іванівни Баринової-Кулеби (нар. 1938) налічує сотні живописних творів, різних за тематикою й манерою візуалізації та стилізації образів, серед яких, окрім портретів й натюрмортів, домінують українські фольклорні зображення, пасторальні сцени. Зауважимо, що мисткиня нерідко звертається до анімалістичного жанру, змальовуючи на своїх полотнах побут українського села, з його звичаями та традиціями, зображуючи поряд 3 людьми тварин. Саме тому анімалістичні образи у творчості В. Баринової-Кулеби потребують окремого наукового зосередження.

Анімалістичний - один із найдавніших жанрів образотворчого мистецтва України і світу. Перші зображення тварин, що збереглись дотепер, відомі нам ще $з$ періоду пізнього палеоліту. В усі часи люди малювали тварин та птахів, надаючи своїм зображенням певних символічних значень, які можливо зрозуміти, лише дослідивши контекст.

Творчий шлях української художниці й педагога Віри БариновоїКулеби розпочався на хуторі Мельникове-Кулебине на Полтавщині. Про це мисткиня написала триптих «Ото ж було...» (2017; іл. 1), на центральній частині якого окремим текстуальним фрагментом виділено: «Ото ж було... 1940 р. Хутір Мельнико-Кулебино переселяли у село Римарівку, Гадяцького р-н, Полтавської обл. ближче до колгоспу. <...> Зруйнували церкву на іконах обдирали позолоту. <..> Моя баба спасла одну ікону, замотавши у мішок. Батько тяг із усім збіжжям гарбу. Мама несла Петруся і трьох курей. Я переляканого 
котика. Ікона як «Пам'ять». Ото ж було... I тепер є» [7, с. 166-167]. На прикладі зображення художницею себе 3 котиком на триптиху простежуємо зв’язок з іконографією католицької святої Гертруди Нівельської, покровительки котів.
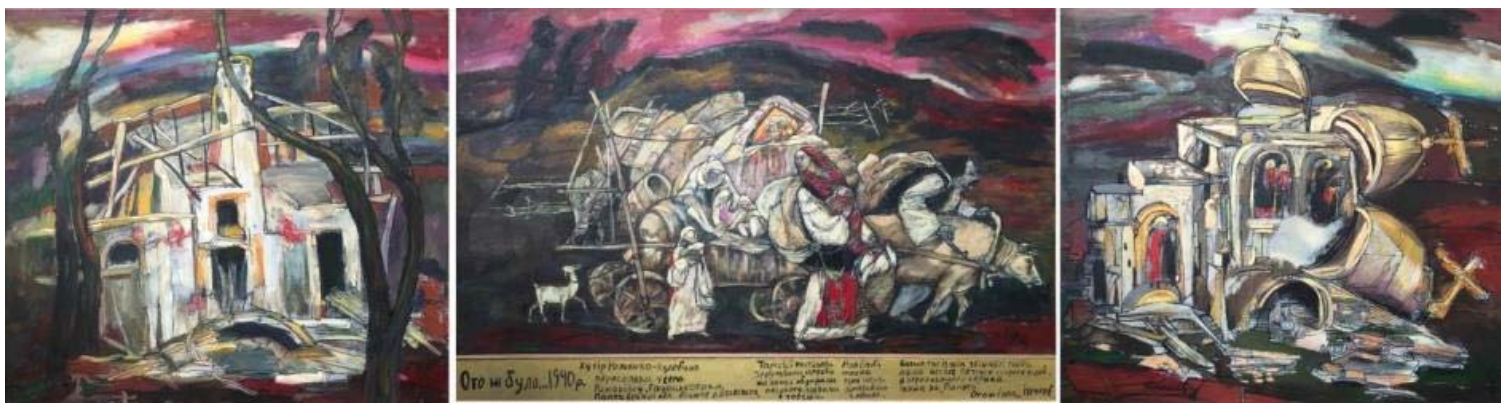

Іл. 1. Віра Баринова-Кулеба. «Ото ж було...». 2017.

Полотно, олія. $80 \times 190$

Перші уроки малювання мисткиня отримала від мами, простої селянської жінки: «Наприклад, дерево. Якщо це яблуня чи груша, то треба взяти папірчик і зобразити плоди - яблуко і грушку, а тоді перевернути малюнок догори низом і побачимо ту форму, яку має саме дерево. Яблуні круглі й пишні, груші продовгуваті. Коли малюєш коня, то спочатку треба вигнути на малюнку спину - бо на нього сідають, курку ж треба починати, окресливши форму яйця» [3, с. 1].

Розглядаючи твори Віри Баринової-Кулеби за хронологією, можемо акцентувати на певних особливостях, зокрема, до початку 1990-х рр. мисткиня пише великі класичні полотна, побудовані на засадах академічної школи, здобутої за час навчання у Харківському державному художньому училищі (1954-1959; педагоги з фаху - А. Луценко, А. Константинопольський, М. Саблін, Ю. Стаханов) та Київському державному художньому інституті у 1959-1965 pp. (КДХІ, з 2000 року Національна академія образотворчого мистецтва і архітектури (НАОМА); педагоги з фаху - О. Будников, В. Виродова-Готьє, B. Костецький, С. Подерв'янський, В. Пузирков, О. Сиротенко, М. Стороженко, К. Трохименко, І. Штільман). Спостерігається зв'язок iз творами Рембрандта Харменса ван Рейна в картинах художниці «1941 (роки війни)» (1978-1980), «А мені сниться» (1985). Зауважимо, що перебуваючи під впливом творчості нідерландського художника мисткиня певний час їздила до музеїв, аналізувала техніку його письма. В пізніших творах В. Баринової-Кулеби простежується вплив сакрального мистецтва, починаються експерименти з кольором, стилем та технічними прийомами, що виявлено на прикладі картин «Моє голодне дитинство 1946-1947 рр.» (1988), «Моя мама і брат» (1989), 154 
«Завтра неділя» (1989), «Моя мама і брат» (1989), «Стара груша» (1989), «Сузір'я бика» (1989), «Батько і стебельце» (1992), «Сон» (1997), «Сину, це твоя земля» (1999).

На початку XXI століття створені нею образи стають більш площинними, узагальненими, 3 крупними масами колірних плям, рисунок означений введенням пластичної лінії-контуру, що бачимо в роботах «Запрошення» (2001), «Нічого кращого немає» (2003), «Радість в танцях» (2006), «На Сорочинському ярмарку» (2007) [2, с. 39-47]. Здебільшого у цей період також з'являються стилізовані сюжети про дитинство, материнство, родину, події з історії України. У творчих циклах картин мисткині початку XXI ст. важливе місце відведене також зображенню сцен з селянського життя - українських пасторалей, які сповнені анімалістичних образів.

Пастораль - метажанр в літературі, театрі, балеті, музиці й образотворчому мистецтві XIV - XVIII ст., що характеризується зображенням ідилії життя пастухів, де дійство часто відбувається на лоні природи. Виникли пасторалі внаслідок поєднання подібних за змістовим наповненням жанрів - провансу та фольку. Йдеться про зображення зустрічі на тлі природи головних героїв- лицаря та пастушки, вподобаної ним [4, с. 401].

Віра Баринова-Кулеба пропонує власні стилістичні вирішення, наближені до народного малярства. Здебільшого це полотна невеликого розміру, декоративно-площинно узагальнені, іконописні, написані 3 використанням лінії-контуру. Подекуди мисткиня використовує золоте тло або ж вкраплення золота. Серед пасторальних мотивів, із зображеннями тварин, варто виокремити твори «Сідай, дівчино, на мого коня» (2009), «Пастушок» (2010), «Мій батько у полі» (2010), «Бандурист 3 конем» (2010), «Запрошення» (2019), «Люблю гусей» (2020) «Чоловіче, пора з гусьми додому» (2020).

Особливу увагу варто звернути на використання В. БариновоюКулебою у іiі творах образу гусей. Гуси здавна $є$ символом любові, вірності, свободи. У Стародавньому Сгипті їх вважали саме тими птахами, що відклали яйце, з якого виникло Сонце. Цих птахів також називали посланцями богів. Гусак став емблемою фараонів, котрі, за віруваннями древніх єгиптян, були втіленням Сонця. При інтронізації нового фараона жреці випускали чотирьох гусей як вісників на чотири сторони світу. У кельтській традиції сонячний символізм гусей ототожнювали з символізмом лебедів. У Стародавньому Римі образ гусей споріднювали з богом війни Марсом, а після відомого випадку у 390 році до н.е., коли оклики священних гусей 3 храму Юнони сповістили захисників Капітолію про напад галлів, стали тріумфальною 
емблемою пильності [1]. В образотворчому мистецтві пластична конструкція птаха дозволяє, змальовуючи його в різних ракурсах, надавати композиціям особливої динаміки, непередбачуваних ритмів. Під час навчання у Харківському державному художньому училищі та КДХІ, художниця займалась етологією та бердвочінгом, роблячи багато анімалістичних начерків, ставлячи за мету - вловити рух тварини чи птаха, що стало в пригоді при написанні майбутніх робіт.

Отже, можемо твердити, що використання анімалістичних образів, елементів сільського побуту, традицій, фольклору та інших народних джерел $є$ означальними рисами творчості Віри Іванівни БариновоїКулеби.

\section{Література:}

1. Гусь (символ). Мегаэнизиклопедия Кирилла и Мефодия. 20082021. URL: https://megabook.ru/article/\%D0\%93\%D1\%83\%D1\%81\%D1\% $8 \mathrm{C} \% 20(\% \mathrm{D} 1 \% 81 \% \mathrm{D} 0 \% \mathrm{~B} 8 \% \mathrm{D} 0 \% \mathrm{BC} \% \mathrm{D} 0 \% \mathrm{~B} 2 \% \mathrm{D} 0 \% \mathrm{BE} \% \mathrm{D} 0 \% \mathrm{BB})$ (дата звернення: 06.07.2021).

2. Денисюк О., Поліщук А. Тема материнства у творчості В. І. Баринової-Кулеби. Актуальні питання гуманітарних наук : міжвуз. зб. наук. пр. молодих вчених Дрогоб. держ. пед. ун-ту ім. І. Франка. Дрогобич, 2019. Вип. 26. Т. 1. С. 39-47.

3. Інтерв'ю Романа Петрука 3 Вірою Бариновою-Кулебою 24 жовт., 2020 р. : [особ. архів автора]. [Б. м.], [2020]. С. 1-3.

4. Лексикон загального та порівняльного літературознавства / голова ред. А. Волков. Чернівці : Золоті литаври. 2001. С. 401.

5. Петрук P. I. Творча й педагогічна іпостасі професора В. І. Баринової-Кулеби. Актуальні питання гуманітарних наук : міжвуз. зб. наук. пр. молодих вчених Дрогоб. держ. пед. ун-ту ім. І. Франка. Дрогобич, 2020. Вип. 34. Т. 4. С. 10-19.

6. Петрук Р. І. Творча особистість професора Віри Іванівни Баринової-Кулеби. Восьмі Платонівські читання : тези доп. Міжнар. наук. конф. Київ : НАОМА, 2020. С. 131-132.

7. Україна від Трипілля до сьогодення в образах сучасних художників : каталог / НСХУ. Київ, 2018. С. 166-167. 